\title{
Brazilian science paralysed by economic slump
}

\section{From unpaid electricity bills to delayed participation in a telescope project, funding cuts bite.}

\section{BY ELIZABETH GIBNEY}

$\mathrm{F}$ or a decade, biochemist Octavio Franco has watched Brazil's economy boom and its research investment surge. "We're starting to do really high-quality science," he says. But as the nation's economy stalls, Franco is one of many who fear that this budding research ecosysytem is in jeopardy.

In 2013, growth decelerated in what was once one of the fastest-growing economies in the world; in 2014, it all but stopped. Over the past year, the resulting cuts to federal and state science funding have paralysed research, says João Calixto, a biomedical scientist at the Federal University of Santa Catarina. "2015 has been a big mess," agrees Franco, whose two labs at the Catholic University of Brasilia and the Catholic University of Dom Bosco in Campo Grande together employ almost 100 researchers. Although his labs have won 11 grants for 2015 , they have received cash for just 2 of them.

The 2016 budget proposal, which Brazil's President Dilma Rousseff presented to Congress in September, only worsens the situation. It requests $24 \%$ less for the federal Ministry of Science, Technology and Innovation (MCTI) than did the 2015 proposal (see 'Federal funding woes'), and freezes new scholarships in a flagship exchange programme, Science Without Borders. The programme is close to meeting its goal of sending 101,000 Brazilian undergraduate and postgraduate students to top institutions abroad by the end of 2015 , and aims to send a further 100,000 by 2018 .

Federal science felt the squeeze in May, when Rousseff's administration chopped the MCTI's budget by almost 2 billion reais (US\$500 million), or some 25\% (the ministry's spending limit has since shrunk further). Although the MCTI says that it is maintaining existing grants and fellowships, it dropped some regular calls for research proposals and is creating few new programmes. This year, there will be no 'universal call' from the National Council for Scientific and Technological Development (CNPq), a R\$200-million funding stream that last year was allocated to more than 5,000 projects. Junior postdoctoral fellowships part-funded by the CNPq seem to have been frozen from September too, says Franco.

Institutions are struggling to keep their labs going, says Cassio Leandro Barbosa, an

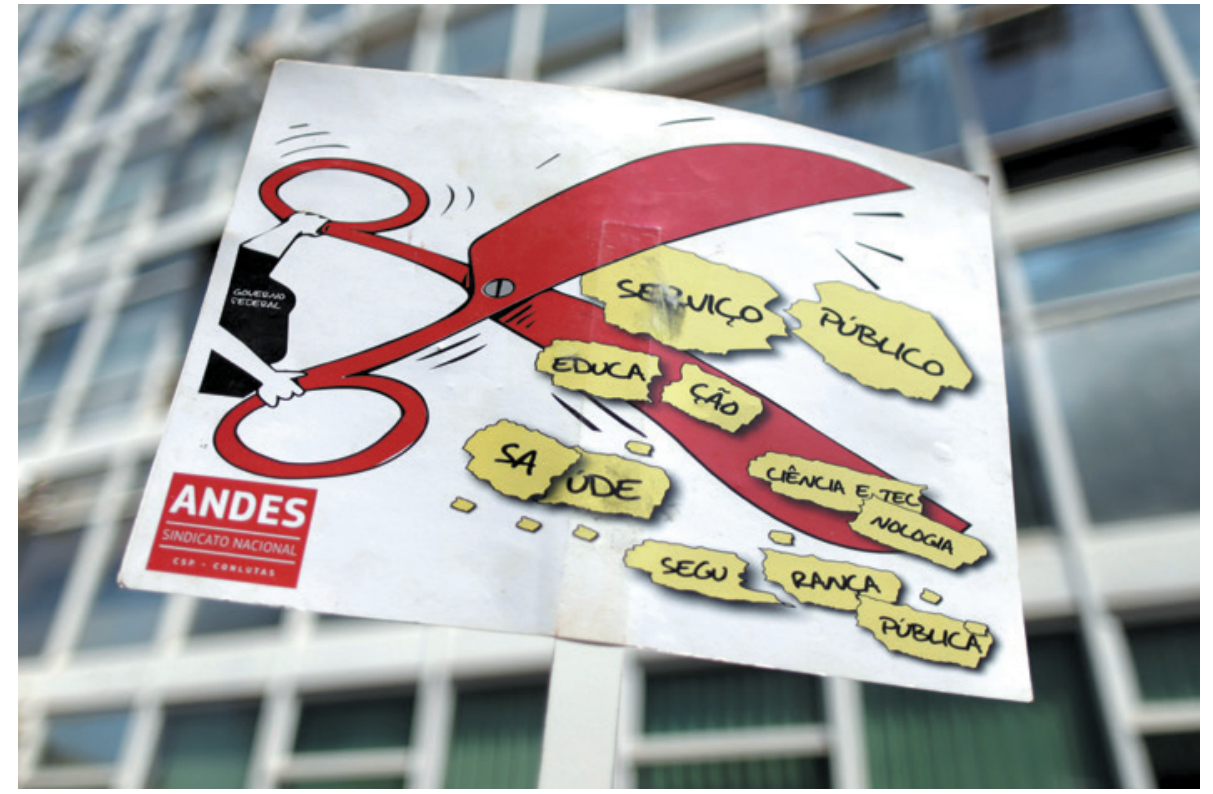

Proposed cuts to government spending have provoked demonstrations in Brasilia.

astronomer formerly at the University of Paraíba Valley in São Paulo state. A 75\% cut to a Ministry of Education graduate programme is making it tough to buy equipment, keep laboratories working and pay travel expenses for field research and meetings. "Some federal institutes don't have funds enough to pay the basics, like electric bills and cleaning," he says. The depreciation of the real has hiked the price of imports, including supplies,

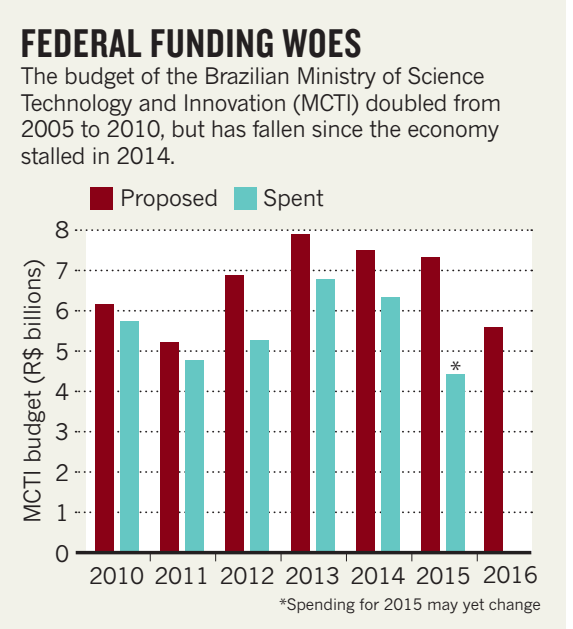

reagents and equipment. And promised government payments have been delayed. "Some institutions may not have received 50\% of their funding yet," adds Barbosa.

Most foreign conference trips have been cancelled, says Vasco Azevedo, a geneticist at the Federal University of Minas Gerais in Belo Horizonte. And attendance at the Brazilian Society of Genetics annual meeting in Águas de Lindóia, São Paulo, this month usually a lively gathering of 3,000 people - was down to less than half its usual level, he estimates. The funding situation also means that Brazil is unlikely to formally join the European Southern Observatory any time soon, Barbosa says, despite its Congress finally ratifying a 2010 agreement earlier this year.

State budgets - an increasingly important source of science funding in Brazil - are feeling the pinch as well. Most states' research funds come from a constitutionally mandated percentage of state revenues, which together amount to billions of reais each year. But many of the smaller, newer state agencies - which often rely on partnerships with embattled federal agencies - are reducing or postponing programmes, some by as much as $50 \%$, says Sergio Gargioni, president of CONFAP, the umbrella organization for state funding 
agencies, based in Brasilia.

Larger states are not immune. Rio de Janeiro's funding agency, which has seen its annual budget treble since 2006 to R $\$ 450$ million, has received less than $60 \%$ of its promised allocation so far this year, says Jerson Lima Silva, the agency's scientific director. And although Brazil's largest and most powerful state funding agency, the São Paulo Research Foundation (FAPESP), has received all of its mandated funds and has an endowment large enough to cover any shortfalls, it is still feeling the bite of shrinking state revenues and the poor exchange rate, says its scientific director, Carlos Henrique de Brito Cruz.

In an effort to revive science spending, science minister Aldo Rebelo is seeking a US\$2-billion loan from the Inter-American Development Bank, headquartered in Washington DC. Among other things, this will help to pay for planned National Science and Technology Institutes. Press reports suggest that the bank has agreed to this, but the MCTI told Nature that the deal requires
"We need to do everything we can to save Brazilian science." government ministries and the Senate.

In a statement, a spokesman for the ministry said that Rebelo is also negotiating with the government to secure some of the $50 \%$ of oil-revenue funds for science that have yet to be allocated. "The MCTI has taken action in order to restore the budget and is seeking new sources of funding for the science and technology system," he said. For example, despite September cuts of $\mathrm{R} \$ 3.8$ billion to a separate government fund called the Growth Acceleration Programme, Rebelo has secured funding for two cuttingedge science facilities that it was to have supported: a synchrotron light source set to come online in 2016 and a research nuclearreactor facility due to open in 2018.

But with Brazil's economy showing no signs of recovery, many fear that the worst is yet to come. After further cuts were announced on 14 September, reports emerged that the government wants to merge the CNPq with CAPES, the Brazilian Federal Agency for the Support and Evaluation of Graduate Education, which is funded by the education ministry. The Brazilian Academy of Sciences and the Brazilian Society for the Advancement of Science, among others, came out strongly against such a move in a letter to the president, citing the agencies' "clear and complementary missions". And Gargioni thinks that the crisis could continue for years. "The situation is so black," says Azevedo. "We had very good graduate programmes and science, and now we will be back to 20 years ago. We need to do everything we can to save Brazilian science." -

\section{Bacteria yield new gene cutter}

\section{Smaller CRISPR enzyme should simplify genome editing.}

\section{BY HEIDI LEDFORD}

$\mathrm{T}$ The CRISPR/Cas9 gene-editing technique is revolutionizing genetic research: scientists have used it to engineer crops, livestock and even human embryos, and it may one day yield new ways to treat disease.

But one of the technique's pioneers thinks that he has found a way to make CRISPR even simpler and more precise. On 25 September, a team led by synthetic biologist Feng Zhang of the Broad Institute in Cambridge, Massachusetts, reported the discovery of a protein that may overcome one of CRISPR/Cas9's few limitations ${ }^{1}$. Called Cpf1, the protein should make it easier to edit genes by replacing one DNA sequence with another, without compromising CRISPR's ability to disable genes.

The CRISPR/Cas9 system evolved as a way for bacteria and archaea to defend themselves against invading viruses. It is found in a wide range of these organisms, and uses an enzyme called Cas9 to cut DNA at a site specified by 'guide' strands of RNA. The cell's natural processes then repair the cuts. Researchers have now turned CRISPR/Cas9 into a molecularbiology powerhouse that can be used in other organisms.

CRISPR is much simpler than previous geneediting methods, but Zhang thought that there was still room for improvement. So he and his colleagues searched the bacterial kingdom to find an alternative to the Cas9 enzyme commonly used in laboratories. In April, they reported ${ }^{2}$ that they had discovered a smaller version of Cas9 in the bacterium Staphylococcus aureus. The small size makes the enzyme easier to shuttle into mature cells - a crucial destination for some potential therapies.

The team was also intrigued by Cpf1, a protein that looks very different from Cas9, but is present in some bacteria that use the CRISPR system. The scientists evaluated Cpf1 enzymes from 16 different bacteria, eventually finding two that could cut human DNA.

They also uncovered some curious variations in how Cpf1 and Cas9 work. Cas9 requires two RNA molecules to cut DNA; Cpf1 needs only one. The proteins also cut DNA at different places, offering researchers more options when selecting a site to edit, says epigeneticist Luca Magnani of Imperial College London.

And Cpf1 cuts DNA in a different way. Cas9 cuts both strands in a DNA molecule at the same position, leaving behind what molecular biologists call 'blunt' ends. But Cpf1 leaves one strand longer than the other, creating a 'sticky' end. Blunt ends are not as easy to work with because a DNA sequence could be inserted in either strand. But a sticky end will only pair with a complementary sticky end.

"The sticky ends carry information that can direct the insertion of the DNA," says Zhang, and that makes the process more controllable.

\section{STICK WITH IT}

Zhang's team is now working to use these sticky ends to improve the frequency with which researchers can replace a natural DNA sequence. Cuts left by Cas 9 tend to be repaired by sticking the two ends back together, a process that can leave errors. Although it is possible that the cell will instead insert a designated new sequence at that site, that kind of repair occurs much less frequently. Zhang hopes that the unique properties of Cpf1 may be harnessed to make such insertions more frequent.

For Bing Yang, a plant biologist at the Iowa State University in Ames, this is the most exciting aspect of Cpf1. "Boosting the efficiency would be a big step for plant science," he says. "Right now, it is a major challenge."

Will the new enzyme surpass Cas9 in popularity? "It's too early to tell," says Zhang. "It certainly has some distinct advantages." The CRISPR/Cas9 system is so popular and potentially lucrative - that it has sparked a fierce patent fight between the University of California, Berkeley, and the Broad Institute and its ally, the Massachusetts Institute of Technology in Cambridge. Zhang says that his lab will make the CRISPR/Cpf1 components available to academic researchers, as it has done with its CRISPR/Cas9 tools.

For now, the results stand as a testament that researchers still have more to learn from the genome-editing systems that bacteria have evolved. Microbiologist John van der Oost of Wageningen University in the Netherlands, who collaborated on the latest study with Zhang, plans to keep searching for new methods. "You never know whether one of these systems will be suitable for genome editing," he says. "There are still surprises ahead of us."

1. Zetsche, B. et al. Cell http://dx.doi.org/10.1016/ j.cell.2015.09.038 (2015).

2. Ran, F. A. et al. Nature 520, 186-191 (2015). 